\title{
Effect of Intercropping and Fertilizer Dose on Seed Quality and Physiological Properties of Chickpea (Cicer arietinum L.)
}

\author{
Basave Gowda $^{1^{*}}$, T. N. Deepak ${ }^{2}$, T. C. Suma ${ }^{3}$, G. S. Yadahalli ${ }^{4}$, \\ Sangeeta I. Maccha ${ }^{2}$ and S. M. Prashanth ${ }^{5}$ \\ ${ }^{1}$ National seed project (Crops), Seed Unit, UAS, Raichur, India \\ ${ }^{2}$ Department of Seed Science and Technology, College of Agriculture, Raichur, India \\ ${ }^{3}$ Department of Crop Physiology, College of Agriculture, Raichur, India \\ ${ }^{4} K V K$, UAS, Raichur, Karnataka, India \\ ${ }^{5} A R S$, UAS, Raichur, India \\ *Corresponding author
}

\section{A B S T R A C T}

Keywords

Intercropping, fertilizer dose, seed germination, seedling vigour index

Article Info

Accepted:

15 December 2019

Available Online:

20 January 2020
The laboratory experiment was conducted at seed unit, UAS, Raichur to study the effect of intercropping system and fertilizer dose on seed quality of chickpea (Cicer arietinum L.). The experiment consists of four intercropping systems viz., sole chickpea, chickpea + sorghum (4:2), chickpea + safflower $(4: 2)$, chickpea + linseed (4:2) and three fertilizer doses includes $100 \%, 125 \%$ and $150 \%$ RDF. The results revealed that among intercropping systems, significantly highest seed germination (93.44 $\%)$, seedling length $(30.02 \mathrm{~cm})$, seedling dry weight $(518.45 \mathrm{mg})$, seedling vigour index I (2806) and II (48446), chlorophyll content (36.12), photosynthetic rate (15.57), transpiration rate (2.29) and lower electrical conductivity $\left(0.647 \mathrm{dSm}^{-1}\right)$ were recorded in sole chickpea compared to other treatments. However the chickpea seeds produced under intercropping meets the minimum seed certification standards.

\section{Introduction}

Chickpea (Cicer arietinum L.) is an important cool season grain legume and is considered as the third most important pulse in the world. Chickpea is cultivated in an area of 13.73 mha with an average yield of $982.1 \mathrm{~kg}$ per ha in the world (Anon, 2017). India is the largest producer of chickpea accounting for about 68 per cent of world's chickpea production. It is cultivated in an area of 9.62 mha with a productivity of $974 \mathrm{~kg}$ per ha (Anon, 2017). Karnataka ranks fifth in the cultivation of chickpea with an area of 10.03 lakh ha and 
productivity of $590 \mathrm{~kg}$ per ha. Intercropping is the agricultural practice where cultivation of two or more crops in the same space at the same time are grown. The most common advantage of intercropping is the production of greater yield on a given piece of land by making more efficient use of available natural resources using a mixture of crops of different rooting ability, canopy structure, height and nutrient requirements based on the complementary utilization of growth resources by the component crops. The efficiency of nutrients may be increased by the fertilizers, which can be applied to manage the combined demand of both the crops.

In the present system, intercropping will be applicable to oilseeds and pulse crops only for production of certified seed. The foundation seed shall be raised strictly as a single crop only. The crops selected for intercropping should belong to different genus and preferably with different maturity. Only the base crop (seed crop) will be registered for certification and companion crop will not be eligible for certification. It should be ensured that the numbers of rows of seed crop alternating with the companion crop are uniform throughout the field. At time of deciding the crop combination, the certification agencies will ensure that companion crop does not hamper the operations and nutrients required for seed crop. Also it does not mature simultaneously with the seed crop and does not carry weed seed which may mix with seed crop at maturity. Keeping this in view, the present study was undertaken to know the effect of intercropping and fertilizer dose on seed quality of chickpea.

\section{Materials and Methods}

The laboratory experiment was conducted at Seed Unit, UAS, Raichur during 2018-19. The experiment consisting of twelve treatment combinations of four cropping systems viz., sole chickpea, sole chickpea, chickpea + sorghum (4:2), chickpea + safflower (4:2) and chickpea + linseed $(4: 2)$ and three different fertilizer doses viz., $100 \%$., $125 \%$ and $150 \%$ $\mathrm{RDF}$ and replicated thrice was laid out in the factorial complete randomized design. Foundation seeds of chickpea, certified seeds of sorghum, safflower and truthfully labelled seeds of linseed were selected and used for sowing. The seeds of chickpea were treated with rhizobium and phosphorous solubilising bacteria before sowing. Treated seeds of chickpea and intercrops were sown at row ratio of 4:2 (chickpea: intercrops) and $3-5 \mathrm{~cm}$ deep with a spacing of $30 \mathrm{~cm}$ between rows and $10 \mathrm{~cm}$ between plants. Soon after sowing, the experimental plots were irrigated lightly to ensure uniform germination and optimum plant stand, later required plant population was maintained by thinning. The resultant seeds of chickpea harvested from the field experiment were assessed for seed quality parameters. The observations on parameters viz., seed germination (\%), seedling length, seedling vigour index I and II, seedling dry weight, electrical conductivity, chlorophyll content, photosynthesis rate and transpiration rate were recorded.

\section{Results and Discussion}

Seed quality and physiological properties are important for proper growth and development of the crop and also to have higher yield. So, the data pertaining to seed germination, seedling length, seedling vigour index I and II, seedling dry weight, electrical conductivity, photosynthetic rate, transpiration rate and chlorophyll content (SPAD value), as influenced by intercropping system and fertilizer levels are presented in the Table 1-5, respectively.

Among the intercropping systems, slightly higher seed germination of chickpea (93.44 
$\%$ ) was recorded in sole crop of chickpea and the lower seed germination of chickpea ( 90.22 $\%)$ was recorded in chickpea + safflower intercropping system and it was on par with chickpea + linseed $\left(\mathrm{C}_{4}\right)$ intercropping system $(92.56 \%)$ (Table 1). This was due to fact that no proper development of seeds that results in less accumulation of food reserves and recorded lower seed weight which ultimately might have registered the lower germination. Richard et al., 2015 reported that seed subjected to high temperature and high relative humidity in the field declined significantly in germination after reaching physiological maturity. Similar results were also reported by Mohsen et al., (2012) in maize intercropping system. However the chickpea seed produced either in sole system or intercropping system recorded seed germination above the minimum standards of 85 per cent. Among the fertilizer levels, higher seed germination was recorded in 150 per cent RDF $(92.58 \%)$ and which was statistically on par with 125 per cent RDF (92.08\%) (Table 1). Increased level of fertilizer improves the seed germination of chickpea. It might be due to activity of certain enzymes responsible for degradation of macromolecules into micro molecules within the seed and also in accumulation of food reserves like carbohydrates, protein and small amount of lipids in seed during harvest which is directly correlated by 100 seed weight (Anitha et al., 2015).

Highest shoot length, root length and seedling length recorded in sole chickpea compared to intercropping system. Significantly higher shoot length, root length and seedling length of chickpea $(11.99,18.04$ and $30.02 \mathrm{~cm}$, respectively) was recorded in sole crop of chickpea and the lower shoot length, root length and seedling length of chickpea (9.64, 15.28 and $24.92 \mathrm{~cm}$, respectively) was recorded in chickpea + safflower intercropping system. It might be due to induction of photosynthesis and synthesis of $\alpha$ amylase, protease and other hydrolytic enzymes that induce the activity of gluconeogenic enzymes during early stage of seed germination cause lengthy seedling and also higher 100 seed weight directly correlated with the higher seedling length (Mohsen et al., 2012). Above results were in agreement with Shahzaman et al., (2017) in sunflower crop reported that shoot length gradually increased with increase of nitrogen containing fertilizers.

Significantly higher seedling dry weight of chickpea (518.45 $\mathrm{mg}$ ) was recorded in sole crop of chickpea and the lower seedling dry weight of chickpea $(516.81 \mathrm{mg})$ was recorded in chickpea + safflower intercropping system (Table 2). Significantly, higher seedling dry weight $(518.3 \mathrm{mg}$ ) was recorded in 150 per cent RDF because higher fertilizer level leads to higher seedling dry weight. Further, these metabolites release certain enzymes responsible for degradation of macromolecules into micro molecules within the seed responsible for the higher growth of seedling which increased the seedling dry weight. Above results were in agreement with Anitha et al., (2015) in Fenugreek.

Significantly higher seedling vigour index-I and II of chickpea (2806 and 48446) was recorded in sole crop of chickpea and the lower seedling vigour index-I and II of chickpea (2248 and 46628) was recorded in chickpea + safflower intercropping system. Immense increase in seedling vigour index was recorded in sole crop of chickpea compared to intercropping system. This was mainly due to higher germination, seedling length and seedling dry weight (Mohsen et al., 2012). Higher seedling vigour index-I and II (2620 and 47971) was recorded in 150 per cent RDF and it was on par with 125 per cent RDF (Table 2). This is mainly due to application of fertilizer dose enhances the accumulation of higher quantities of seed 
constituents like carbohydrates, proteins as enzymes that increased the seedling vigour index of bolder seeds which contain greater metabolites for resumption of embryonic growth during germination (Anitha et al., 2015).

Significantly lower electrical conductivity of chickpea $\left(0.647 \mathrm{dSm}^{-1}\right)$ was recorded in sole crop of chickpea and higher electrical conductivity of chickpea $\left(0.677 \mathrm{dSm}^{-1}\right)$ was recorded in chickpea + safflower intercropping system (Table 2). Higher electrical conductivity was noticed in intercropping system compared to sole cropping because of slightly low germination, less seed viability, high frazzle that increases the membrane damage, disturbance of enzyme activity and other cell structures (Mohsen et al., 2012). They reported that high frazzle increases the membrane damage, disturbance of certain enzyme activity responsible for degradation of macromolecules into micro molecules within the seed and other cell structures. The data on electrical conductivity of chickpea differed significantly due to the influence of different fertilizer levels. Significantly lower electrical conductivity $\left(0.659 \mathrm{dSm}^{-1}\right)$ was recorded in 150 per cent RDF, which was on par with 125 per cent $\operatorname{RDF}\left(0.660 \mathrm{dSm}^{-1}\right)$ (Table 2). Lower electrical conductivity was noticed in higher fertilizer levels, because of low leachate. These evidences were supported by the findings made by Bilekudari et al., (2005) in radish. They reported that higher nutrients level strengthened the cell membrane integrity and resulted in low leachate as indicated by lower EC value.

Significantly, the highest value of chlorophyll content (41.67, 50.70 and 36.12) at 30, 60 DAS and at harvest, respectively was observed in sole chickpea $\left(\mathrm{C}_{1}\right)$ and it was statistically on par with chickpea + linseed
$\left(\mathrm{C}_{4}\right)$ intercropping system $(40.86,49.70$ and 35.30) at 30, 60 DAS and at harvest, respectively. Significantly lowest value of chlorophyll content of chickpea was observed in chickpea + safflower $\left(\mathrm{C}_{3}\right)$ intercropping system (38.80, 47.35 and 33.63) at 30, 60 DAS and at harvest, respectively. Chlorophyll has been rightly designated as "pigments of life" because of its central role in living systems responsible for harvesting sunlight and transforming its light energy into biochemical energy essential for life.

The variation in chlorophyll content due to intercropping system may be attributed to decreased chlorophyll degradation, increased chlorophyll biosynthesis and the development of chloroplasts. From the present investigation, it is clear that maximum chlorophyll content was noticed in sole crop of chickpea, which showed higher intensity of the green colour in the leaves than the intercropped chickpea. It occurred because of the low contribution of supplying $\mathrm{N}$ for intercropped chickpea. These evidences are supported by the findings of Balwindar and Aulakh (2017) in wheat + chickpea intercropping system. With respect to different levels of fertilizer application of 150 per cent RDF $\left(\mathrm{F}_{3}\right)$ recorded significantly higher chlorophyll content (40.75, 49.52 and 35.28) at 30,60 DAS and at harvest, respectively and which was statistically on par with 125 per cent $\operatorname{RDF}\left(\mathrm{F}_{2}\right)$ at different stages of growth period $(40.17,48.94$ and 34.81$)$. The variation in chlorophyll content due to the levels of fertilizer may be attributed to increase in chlorophyll content with increased fertilizer dose. It may be because of the higher contribution of $\mathrm{N}$ content, which might have increased leaf-area duration and thus increased chlorophyll content. These evidences are supported by the findings of Saeid and Maryam (2011) in maize and Bayu et al., (2005) in sorghum. 
Table.1 Effect of intercropping and fertilizer dose on seed germination, shoot length, root length and seedling length of chickpea

\begin{tabular}{|c|c|c|c|c|}
\hline Treatments & $\begin{array}{c}\text { Seed } \\
\text { germination } \\
(\%)\end{array}$ & $\begin{array}{l}\text { Shoot length } \\
(\mathrm{cm})\end{array}$ & $\begin{array}{l}\text { Root length } \\
\text { (cm) }\end{array}$ & $\begin{array}{c}\text { Seedling } \\
\text { length }(\mathrm{cm})\end{array}$ \\
\hline \multicolumn{5}{|c|}{ Factor A: Intercrops ( C ) } \\
\hline $\mathrm{C}_{1}$ - Sole chickpea & 93.44 & 11.99 & 18.04 & 30.03 \\
\hline $\mathrm{C}_{2-}$ - Chickpea+sorghum & 91.56 & 10.69 & 16.72 & 27.41 \\
\hline $\begin{array}{c}\mathrm{C}_{3^{-}} \\
\text {Chickpea+safflower }\end{array}$ & 90.22 & 9.64 & 15.28 & 24.92 \\
\hline $\mathrm{C}_{4^{-}}$Chickpea+linseed & 92.56 & 11.47 & 17.51 & 28.98 \\
\hline S.Em \pm & 0.39 & 0.14 & 0.14 & 0.26 \\
\hline CD at $1 \%$ & 1.12 & 0.40 & 0.41 & 0.75 \\
\hline \multicolumn{5}{|c|}{ Factor B: Fertilizer dose ( F) } \\
\hline $\mathrm{F}_{1-} \mathbf{1 0 0 \%} \mathrm{RDF}$ & 91.17 & 10.71 & 16.66 & 27.37 \\
\hline $\mathrm{F}_{2-} \mathbf{1 2 5 \%} \mathrm{RDF}$ & 92.08 & 10.96 & 16.89 & 27.85 \\
\hline $\mathrm{F}_{3}-150 \% \mathrm{RDF}$ & 92.58 & 11.16 & 17.12 & 28.28 \\
\hline S.Em \pm & 0.33 & 0.12 & 0.12 & 0.22 \\
\hline CD at $1 \%$ & 0.97 & 0.35 & 0.36 & 0.65 \\
\hline \multicolumn{5}{|c|}{ Interaction (C X F) } \\
\hline $\mathbf{C}_{1} \mathbf{F}_{1}$ & 92.67 & 11.71 & 17.73 & 29.43 \\
\hline $\mathbf{C}_{1} \mathbf{F}_{2}$ & 93.67 & 12.06 & 18.08 & 30.14 \\
\hline $\mathbf{C}_{1} \mathbf{F}_{3}$ & 94.00 & 12.20 & 18.30 & 30.50 \\
\hline $\mathbf{C}_{2} \mathbf{F}_{1}$ & 90.67 & 10.41 & 16.43 & 26.83 \\
\hline $\mathbf{C}_{2} \mathbf{F}_{2}$ & 91.33 & 10.71 & 16.77 & 27.46 \\
\hline $\mathrm{C}_{2} \mathbf{F}_{3}$ & 92.67 & 10.95 & 16.97 & 27.93 \\
\hline $\mathbf{C}_{3} \mathbf{F}_{1}$ & 89.33 & 9.40 & 15.13 & 24.53 \\
\hline $\mathbf{C}_{3} \mathbf{F}_{2}$ & 90.67 & 9.61 & 15.29 & 24.90 \\
\hline $\mathrm{C}_{3} \mathrm{~F}_{3}$ & 90.67 & 9.89 & 15.43 & 25.33 \\
\hline $\mathbf{C}_{4} \mathbf{F}_{1}$ & 92.00 & 11.33 & 17.35 & 28.69 \\
\hline $\mathrm{C}_{4} \mathbf{F}_{2}$ & 92.67 & 11.47 & 17.43 & 28.89 \\
\hline $\mathrm{C}_{4} \mathrm{~F}_{3}$ & 93.00 & 11.60 & 17.75 & 29.35 \\
\hline S.Em \pm & 0.67 & 0.24 & 0.24 & 0.44 \\
\hline CD at $1 \%$ & NS & NS & $\mathrm{NS}$ & NS \\
\hline
\end{tabular}


Table.2 Effect of intercropping and fertilizer dose on seedling dry weight, seedling vigour index I and II and electrical conductivity of chickpea

\begin{tabular}{|c|c|c|c|c|}
\hline Treatments & $\begin{array}{l}\text { Seedling dry } \\
\text { weight (mg) }\end{array}$ & $\begin{array}{l}\text { Seedling vigour } \\
\text { index I }\end{array}$ & $\begin{array}{c}\text { Seedling } \\
\text { vigour index II }\end{array}$ & $\begin{array}{c}\text { electrical } \\
\text { conductivity } \\
\left(\mathbf{d S m}^{-1}\right)\end{array}$ \\
\hline \multicolumn{4}{|c|}{ Factor A: Intercrops ( C ) } & \\
\hline $\mathrm{C}_{1}$ - Sole chickpea & 518.45 & 2806 & 48446 & 0.647 \\
\hline $\begin{array}{c}\mathrm{C}_{2^{-}} \\
\text {Chickpea+sorghum }\end{array}$ & 517.61 & 2510 & 47390 & 0.668 \\
\hline $\begin{array}{c}\mathrm{C}_{3^{-}} \\
\text {Chickpea+safflower }\end{array}$ & 516.81 & 2248 & 46628 & 0.677 \\
\hline $\mathrm{C}_{4}$ - Chickpea+linseed & 518.09 & 2682 & 47953 & 0.660 \\
\hline S.Em \pm & 0.24 & 25 & 200 & 0.002 \\
\hline CD at $1 \%$ & 0.71 & 74 & 584 & 0.006 \\
\hline \multicolumn{4}{|c|}{ Factor B: Fertilizer dose ( F) } & \\
\hline $\mathrm{F}_{1}-100 \% \mathrm{RDF}$ & 517.34 & 2498 & 47164 & 0.670 \\
\hline $\mathrm{F}_{2-} \mathbf{1 2 5 \%} \mathrm{RDF}$ & 517.76 & 2567 & 47678 & 0.660 \\
\hline $\mathrm{F}_{3}-150 \% \mathrm{RDF}$ & 518.13 & 2620 & 47971 & 0.659 \\
\hline S.Em \pm & 0.21 & 22 & 173 & 0.002 \\
\hline CD at $1 \%$ & 0.61 & 64 & 505 & 0.005 \\
\hline \multicolumn{4}{|c|}{ Interaction (C X F) } & \\
\hline $\mathbf{C}_{1} \mathbf{F}_{1}$ & 517.87 & 2727 & 47989 & 0.653 \\
\hline $\mathbf{C}_{1} \mathbf{F}_{2}$ & 518.62 & 2823 & 48578 & 0.646 \\
\hline $\mathbf{C}_{1} \mathbf{F}_{3}$ & 518.85 & 2867 & 48771 & 0.642 \\
\hline $\mathbf{C}_{2} \mathbf{F}_{1}$ & 517.37 & 2432 & 46908 & 0.675 \\
\hline $\mathbf{C}_{2} \mathbf{F}_{2}$ & 517.63 & 2508 & 47278 & 0.666 \\
\hline $\mathbf{C}_{2} \mathbf{F}_{3}$ & 517.83 & 2588 & 47986 & 0.664 \\
\hline $\mathrm{C}_{3} \mathrm{~F}_{1}$ & 516.43 & 2191 & 46134 & 0.685 \\
\hline $\mathbf{C}_{3} \mathbf{F}_{2}$ & 516.80 & 2258 & 46857 & 0.670 \\
\hline $\mathrm{C}_{3} \mathrm{~F}_{3}$ & 517.20 & 2296 & 46893 & 0.675 \\
\hline $\mathbf{C}_{4} \mathbf{F}_{1}$ & 517.97 & 2639 & 47627 & 0.668 \\
\hline $\mathrm{C}_{4} \mathbf{F}_{2}$ & 517.97 & 2678 & 47999 & 0.658 \\
\hline $\mathrm{C}_{4} \mathbf{F}_{3}$ & 518.62 & 2729 & 48232 & 0.654 \\
\hline S.Em \pm & 0.42 & 44 & 346 & 0.004 \\
\hline CD at $1 \%$ & NS & NS & NS & NS \\
\hline
\end{tabular}


Table.3 Effect of intercropping and fertilizer dose on chlorophyll content (SPAD values) at different crop growth stages of chickpea

\begin{tabular}{|c|c|c|c|}
\hline \multirow[t]{2}{*}{ Treatments } & \multicolumn{3}{|c|}{ Chlorophyll content (SPAD value) } \\
\hline & 30DAS & 60DAS & At harvest \\
\hline \multicolumn{4}{|c|}{ Factor A: Intercrops ( C ) } \\
\hline $\mathrm{C}_{1}$ - Sole chickpea & 41.67 & 50.70 & 36.12 \\
\hline $\mathrm{C}_{2}$ - Chickpea+sorghum & 39.08 & 47.82 & 33.86 \\
\hline $\mathrm{C}_{3^{-}}$Chickpea+safflower & 38.80 & 47.35 & 33.63 \\
\hline $\mathrm{C}_{4}$ - Chickpea+linseed & 40.86 & 49.74 & 35.30 \\
\hline S.Em \pm & 0.29 & 0.33 & 0.29 \\
\hline CD at $5 \%$ & 0.86 & 0.98 & 0.85 \\
\hline \multicolumn{4}{|c|}{ Factor B: Fertilizer dose ( F) } \\
\hline$F_{1}-100 \%$ RDF & 39.40 & 48.35 & 34.10 \\
\hline$F_{2}-125 \%$ RDF & 40.17 & 48.94 & 34.81 \\
\hline$F_{3^{-}} 150 \%$ RDF & 40.75 & 49.42 & 35.28 \\
\hline S.Em \pm & 0.25 & 0.29 & 0.25 \\
\hline CD at $5 \%$ & 0.75 & 0.84 & 0.74 \\
\hline \multicolumn{4}{|c|}{ Interaction $(\mathbf{C} \times \mathbf{F})$} \\
\hline $\mathbf{C}_{1} \mathbf{F}_{1}$ & 41.11 & 49.86 & 35.46 \\
\hline $\mathbf{C}_{1} \mathbf{F}_{2}$ & 41.63 & 50.77 & 36.37 \\
\hline $\mathbf{C}_{1} \mathbf{F}_{3}$ & 42.27 & 51.48 & 36.53 \\
\hline $\mathbf{C}_{2} \mathbf{F}_{1}$ & 38.33 & 47.43 & 33.11 \\
\hline $\mathbf{C}_{2} \mathbf{F}_{2}$ & 39.16 & 47.77 & 33.94 \\
\hline $\mathbf{C}_{2} \mathbf{F}_{3}$ & 39.76 & 48.27 & 34.54 \\
\hline $\mathbf{C}_{3} \mathbf{F}_{1}$ & 38.37 & 47.05 & 33.28 \\
\hline $\mathbf{C}_{3} \mathbf{F}_{2}$ & 38.67 & 47.43 & 33.45 \\
\hline $\mathbf{C}_{3} \mathbf{F}_{3}$ & 39.37 & 47.57 & 34.15 \\
\hline $\mathrm{C}_{4} \mathbf{F}_{1}$ & 39.77 & 49.07 & 34.55 \\
\hline $\mathbf{C}_{4} \mathbf{F}_{2}$ & 41.22 & 49.80 & 35.47 \\
\hline $\mathrm{C}_{4} \mathrm{~F}_{3}$ & 41.60 & 50.36 & 35.90 \\
\hline S.Em \pm & 0.51 & 0.58 & 0.50 \\
\hline CD at $5 \%$ & NS & NS & NS \\
\hline
\end{tabular}


Table.4 Effect of intercropping and fertilizer dose on photosynthetic rate at different crop growth stages of chickpea

\begin{tabular}{|c|c|c|c|}
\hline \multirow[t]{2}{*}{ Treatments } & \multicolumn{3}{|c|}{ Photosynthetic rate $\left(\mu \mathrm{mol} \mathrm{CO} \mathrm{CO}_{2}^{-2} \mathrm{~s}^{-1}\right)$} \\
\hline & 30DAS & 60DAS & At harvest \\
\hline \multicolumn{4}{|c|}{ Factor A: Intercrops ( C ) } \\
\hline $\mathrm{C}_{1^{-}}$Sole chickpea & 9.60 & 13.11 & 15.57 \\
\hline $\mathrm{C}_{2}$ - Chickpea+sorghum & 8.54 & 12.28 & 14.50 \\
\hline $\mathrm{C}_{3^{-}}$Chickpea+safflower & 8.43 & 11.96 & 13.78 \\
\hline $\mathrm{C}_{4}$ - Chickpea+linseed & 9.44 & 12.52 & 15.05 \\
\hline S.Em \pm & 0.10 & 0.27 & 0.35 \\
\hline CD at $5 \%$ & 0.30 & 0.79 & 1.03 \\
\hline \multicolumn{4}{|c|}{ Factor B: Fertilizer dose ( F) } \\
\hline$F_{1}-100 \%$ RDF & 8.76 & 11.98 & 14.16 \\
\hline$F_{2-} 125 \%$ RDF & 9.03 & 12.44 & 14.67 \\
\hline $\mathrm{F}_{3}-150 \%$ RDF & 9.22 & 12.98 & 15.34 \\
\hline S.Em \pm & 0.09 & 0.23 & 0.30 \\
\hline CD at $5 \%$ & 0.26 & 0.68 & 0.89 \\
\hline \multicolumn{4}{|c|}{ Interaction $(\mathbf{C} \times \mathbf{F})$} \\
\hline $\mathbf{C}_{1} \mathbf{F}_{1}$ & 9.43 & 12.56 & 15.07 \\
\hline $\mathbf{C}_{1} \mathbf{F}_{2}$ & 9.64 & 13.21 & 15.47 \\
\hline $\mathbf{C}_{1} \mathbf{F}_{3}$ & 9.73 & 13.57 & 16.17 \\
\hline $\mathrm{C}_{2} \mathbf{F}_{1}$ & 8.17 & 11.76 & 13.80 \\
\hline $\mathbf{C}_{2} \mathbf{F}_{2}$ & 8.62 & 12.31 & 14.59 \\
\hline $\mathrm{C}_{2} \mathbf{F}_{3}$ & 8.83 & 12.77 & 15.12 \\
\hline $\mathbf{C}_{3} \mathbf{F}_{1}$ & 8.20 & 11.59 & 13.33 \\
\hline $\mathbf{C}_{3} \mathbf{F}_{2}$ & 8.42 & 11.86 & 13.57 \\
\hline $\mathbf{C}_{3} \mathbf{F}_{3}$ & 8.68 & 12.43 & 14.43 \\
\hline $\mathbf{C}_{4} F_{1}$ & 9.25 & 12.00 & 14.46 \\
\hline $\mathbf{C}_{4} \mathbf{F}_{2}$ & 9.46 & 12.40 & 15.06 \\
\hline $\mathrm{C}_{4} \mathrm{~F}_{3}$ & 9.62 & 13.15 & 15.63 \\
\hline S.Em \pm & 0.18 & 0.47 & 0.61 \\
\hline CD at $5 \%$ & NS & NS & NS \\
\hline
\end{tabular}


Table.5 Effect of intercropping and fertilizer dose on transpiration rate at different crop growth stages of chickpea

\begin{tabular}{|c|c|c|c|}
\hline \multirow[t]{2}{*}{ Treatments } & \multicolumn{3}{|c|}{ Transpiration rate $\left(\mathrm{m} \mathrm{mol} \mathrm{H}_{2} \mathrm{O} \mathrm{m}^{-2} \mathrm{~s}^{-1}\right)$} \\
\hline & 30DAS & 60DAS & At harvest \\
\hline \multicolumn{4}{|c|}{ Factor A: Intercrops ( C ) } \\
\hline$C_{1}$ - Sole chickpea & 4.23 & 3.31 & 2.29 \\
\hline $\mathrm{C}_{2}$ - Chickpea+sorghum & 3.50 & 2.18 & 1.76 \\
\hline $\begin{array}{c}\mathrm{C}_{3^{-}} \\
\text {Chickpea+safflower }\end{array}$ & 3.30 & 2.12 & 1.70 \\
\hline $\mathrm{C}_{4^{-}}$Chickpea+linseed & 4.08 & 3.14 & 2.12 \\
\hline S.Em \pm & 0.08 & 0.07 & 0.08 \\
\hline CD at $5 \%$ & 0.23 & 0.21 & 0.22 \\
\hline \multicolumn{4}{|c|}{ Factor B: Fertilizer dose ( F) } \\
\hline $\mathrm{F}_{1}-100 \% \mathrm{RDF}$ & 3.60 & 2.41 & 1.77 \\
\hline$F_{2}-125 \%$ RDF & 3.78 & 2.75 & 1.98 \\
\hline$F_{3^{-}}-150 \%$ RDF & 3.95 & 2.90 & 2.15 \\
\hline S.Em \pm & 0.07 & 0.06 & 0.07 \\
\hline CD at $5 \%$ & 0.20 & 0.18 & 0.19 \\
\hline \multicolumn{4}{|c|}{ Interaction $(\mathbf{C} \times \mathbf{F})$} \\
\hline $\mathbf{C}_{1} \mathbf{F}_{1}$ & 4.15 & 3.12 & 2.10 \\
\hline $\mathbf{C}_{1} \mathbf{F}_{2}$ & 4.23 & 3.35 & 2.33 \\
\hline $\mathbf{C}_{1} \mathbf{F}_{3}$ & 4.30 & 3.47 & 2.43 \\
\hline $\mathbf{C}_{2} \mathbf{F}_{1}$ & 3.21 & 1.79 & 1.51 \\
\hline $\mathbf{C}_{2} \mathbf{F}_{2}$ & 3.53 & 2.30 & 1.79 \\
\hline $\mathbf{C}_{2} \mathbf{F}_{3}$ & 3.77 & 2.45 & 1.97 \\
\hline $\mathbf{C}_{3} \mathbf{F}_{1}$ & 3.15 & 1.85 & 1.51 \\
\hline $\mathbf{C}_{3} \mathbf{F}_{2}$ & 3.25 & 2.21 & 1.73 \\
\hline $\mathbf{C}_{3} \mathbf{F}_{3}$ & 3.50 & 2.30 & 1.87 \\
\hline $\mathbf{C}_{4} \mathbf{F}_{1}$ & 3.88 & 2.89 & 1.97 \\
\hline $\mathbf{C}_{4} \mathbf{F}_{2}$ & 4.12 & 3.15 & 2.07 \\
\hline $\mathbf{C}_{4} \mathbf{F}_{3}$ & 4.23 & 3.36 & 2.33 \\
\hline S.Em \pm & 0.14 & 0.13 & 0.13 \\
\hline CD at $5 \%$ & NS & NS & NS \\
\hline
\end{tabular}

Sole crop of chickpea $\left(\mathrm{C}_{1}\right)$ recorded significantly higher photosynthetic rate $(9.60$, 13.11 and 15.57) at 30, 60 DAS and at harvest, respectively compared to rest of intercropping system. It was found statistically on par with chickpea + linseed $\left(\mathrm{C}_{4}\right)$ intercropping system $(9.44,12.52$ and 15.05$)$ at 30,60 DAS and at harvest, respectively. Significantly lower photosynthetic rate of chickpea was observed in chickpea + safflower $\left(\mathrm{C}_{3}\right)$ intercropping system (8.43, 11.96 and 13.78) at 30, 60 DAS and at harvest, respectively. Photosynthesis is the basic physiochemical process for plant growth, by which plants use light energy to drive the synthesis of organic compounds. The variation in photosynthetic rate due to intercropping system may be attributed to low 
radiation with higher fraction of diffused lights having significant effects on morphological and physiological characteristics of plants. These evidences are supported by the findings of Song et al., (2013) in maize + soybean intercropping system. He reported that reduction of photosynthesis caused by limitations of mesophyll process rather than stomatal limitation. Imran et al., (2013) also reported same results. Among the different fertilizer levels, the value of photosynthetic rate significantly increased in 150 per cent RDF $\left(\mathrm{F}_{3}\right)(9.22,12.98$ and 15.34$)$ at 30,60 DAS and at harvest, respectively and which was statistically on par with 125 per cent RDF $\left(\mathrm{F}_{2}\right)$ at all growth stages (9.03, 12.44 and 14.67). The variation in photosynthetic rate due to the levels of fertilizer may be attributed to increased chlorophyll content with increased fertilizer dose. It occurred because of the higher contribution of $\mathrm{N}$ content, which might have increased leaf-area duration and thus promoted higher rates of photosynthesis. These evidences are supported by the findings of Saeid and Maryam (2011) in maize and Bayu et al., (2005) in sorghum.

Significantly, the highest transpiration rate $(4.23,3.31$ and 2.29$)$ at 30,60 DAS and at harvest, respectively was observed in sole chickpea $\left(\mathrm{C}_{1}\right)$ and it was statistically on par with chickpea + linseed $\left(\mathrm{C}_{4}\right)$ intercropping system $(4.08,3.14$ and 2.12$)$ at 30,60 DAS and at harvest, respectively. Significantly lowest transpiration rate of chickpea was observed in chickpea + safflower $\left(\mathrm{C}_{4}\right)$ (3.30, 2.12 and 1.70) at 30,60 DAS and at harvest, respectively. The transpiration rate was low at harvest in sole chickpea as well as intercropping system, because of the shedding and drying of leaves as the crop is at flag end of its life cycle. These evidences are supported by the findings of Song et al., (2013) in maize + soybean intercropping system. With respect to different levels of fertilizer, application of
150 per cent RDF $\left(\mathrm{F}_{3}\right)$ recorded significantly higher transpiration rate $(3.95,2.90$ and 2.15$)$ at 30, 60 DAS and The variation in transpiration rate due to the levels of fertilizer may be attributed to increased photosynthetic rate with increased fertilizer dose. It might be due to higher chlorophyll content and leaf area which increased photosynthesis with decreased transpiration rate. These evidences are supported by the findings of Saeid and Maryam (2011) in maize and Bayu et al., (2005) in sorghum.

Interaction effect of intercropping system and fertilizer levels were found non-significant for seed quality parameters of chickpea.

From the above results it can be concluded that chickpea grown as sole crop with application of 150 per cent RDF holds promise for quality seed production.

\section{References}

Anitha, M., Swami, D. V. and Suneetha, D. R., 2015, Seed yield and quality of fenugreek cv. Lam methi-2 as influenced by integrated nutrient management. The Biascan, 10(1): 103106.

Anonymous, Food and Agriculture organization, 2017.

Balwinder, S. and Aulakh, C. S., 2017, Effect on growth and yield of intercrops in wheat and chickpea intercropping under limited nutrition and moisture. Indian J. Ecology., 44(5): 507-511.

Bayu, W. G., Rethman, P. S., Hammes and Alemu, G., 2005, Effects of farmyard manure and inorganic fertilizers on sorghum growth, yield, and nitrogen use in a semi-arid area of Ethiopia. $J$. Pl. Nutrition., 29(2): 391-407.

Bilekudari, V. K., Deshpande, V. K. and Shekhargouda, M., 2005, Effect of spacing and ferilizer levels on growth, 
seed yield and quality of radish. Karnataka J. Agric. Sci., 18(2): 338342.

Imran, A., Cheng, Z., Huanwen, M., Wasila, H. and Abdul, R. K., 2013, Effect of intercropped garlic on chlorophyll contents, photosynthesis and antioxidant enzymes in pepper. Pak. $J$. Bot., 45(6): 1889-1896.

Mohsen, F., Mostafa, A. and Shokouh, D., 2012, Effect of intercropping on vigor of seed corn. Ann. Bio. Res., 3(8): 3962-3967.

Richard, W., Naliaka, P. and Simiyu, M. J., 2015, Seed quality of three soybean varities as influenced by intercropping time and arrangement in maize. African J. Agril. Res., 10(6): 505-514.
Saeid, H. and Maryam, H. D., 2011, Effects of nitrogen fertilizer on chlorophyll content and other leaf indicate in three cultivars of maize (Zea mays L.). World Applied Sciences Journal, 15(12): 1780-1785.

Shahzaman, M., Ishtiaq, M. and Azam, A., 2017, Effect of different fertilizers on seed germination and seedling growth of sunflower (Helianthus annuus L.). Int. J. Botany Studies., 2(2): 10-15.

Song, Y. X., Su, B. Y., Song, C., Cui, L., Yong, T. W. and Yang, W. Y., 2013, Growth and photosynthetic response of soybean seedlings to maize shading in relay intercropping system in southwest china. Photosynthetica, 52(10): 316

\section{How to cite this article:}

Basave Gowda, T. N. Deepak, T. C. Suma, G. S. Yadahalli, Sangeeta I. Maccha and Prashanth, S. M. 2020. Effect of Intercropping and Fertilizer Dose on Seed Quality and Physiological Properties of Chickpea (Cicer arietinum L.). Int.J.Curr.Microbiol.App.Sci. 9(01): 591-601. doi: https://doi.org/10.20546/ijcmas.2020.901.064 